\title{
In Between 21st Century Skills and Constructivism in ELT: Designing a Model Derived From a Narrative Literature Review
}

\author{
Suheyla Demirkol Orak ${ }^{1} \&$ Mohammad H. Al-khresheh ${ }^{2}$ \\ ${ }^{1}$ School of Foreign Languages, Firat University, Turkey \\ ${ }^{2}$ Department of English Language, Faculty of Science and Arts, Northern Border University, Saudi Arabia \\ Correspondence: Suheyla Demirkol Orak, School of Foreign Languages, Firat University, Turkey.
}

Received: July 6, 2021

Accepted: September 18, $2021 \quad$ Online Published: September 24, 2021

doi:10.5430/wjel.v11n2p166

URL: https://doi.org/10.5430/wjel.v11n2p166

\begin{abstract}
While the $21^{\text {st }}$-century demands the learners to be technologically competent and self-driven to cope with technological advancement, the educational practitioners find it challenging to prepare the young learners to keep pace with this demand. However, in doing so, to prepare the learners as adaptable to the $21^{\text {st }}$-century demands, constructivism can be envisaged as the most time-appropriate and updated theory of the teaching-learning process, compared to other approaches. Specifically, because one of the requirements from the learners of the $21^{\text {st }}$-century is to be self-driven and take ownership of the learning, constructivism is the closest theory to achieve this goal. This position paper aims to build a procedural link within $21^{\text {st }}$-century expectations and its cooperation with the constructivist learning approach. The paper also offers a design for constructivist teaching in ELT classrooms in the $21^{\text {st }}$-century and defines the role of teachers and students, as established by the literature.
\end{abstract}

Keywords: andragogy and ELT, constructivism and ELT, heutagogy and ELT, $21^{\text {st }}$-century skills, $21^{\text {st }}$-century language education

\section{Introduction}

In the era of the $21^{\text {st }}$-century, the outcomes of dynamic technological advancement reflect on every aspect of our everyday life (Keser \& Semerci, 2019). Especially in the education sector, the highest priority of utilising this technological advancement is given to preparing the students for the $21^{\text {st }}$-century requirements and enabling them to adopt the competitive nature of the world in the $21^{\text {st }}$-century (Raja \& Nagasubramani, 2018). However, among all the educational disciplines, language education can be considered one of the most important, aspects of the $21^{\text {st }}$-century is globalisation, and language is the only means to become a global citizen (Mahdum, 2018; Estaji \& Savarabadi, 2020). Language education enables an individual, regardless of their residence, to use the advantage of the global data stream through a common language (Moeller \& Abbott, 2018). This leads to the underlying justification that enabling the global citizens to utilise this global data stream provokes a common language between the parties of this information exchange in a global context.

The ability of an individual to use this common language of the global data stream depends on the individual's inhabiting country's strength of education policy (Flores \& Chaparro, 2018). In addition to a strong education policy, preparing well-equipped, competitive individuals with a high level of awareness is one of the primary demands of the $21^{\text {st }}$-century (Bedir, 2019). From this perspective, Ministries of education of both developed and developing nations worldwide search for new methods, technics, approaches, and even theories to employ in the educational institutions to achieve these goals. Not only that, politicians, economists, educators, researchers, and teachers also recognise and try to address this issue to meet the demands of the $21^{\text {st }}$-century.

However, inevitably, this search for new methods or approaches of even theories of education is not an easy task, and it can be advised that the most realistic attempt would be to evaluate the outcomes of the past and reflect on the improvisation of the present (Kumaravadivelu, 2003a). The majority of the presently utilised teaching methods and theories are criticised in the assertation of being ill-equipped 'Theory of Practice' models (Kumaravadivelu, 2003b). Thus, these learning methods and theories require improvisation, considering it is not justified to expect the advanced required results of $21^{\text {st }}$-century goals gained through ill-equipped teaching ways that have been continued 
from the previous century. While deeply observing the nature of the $21^{\text {st }}$-century, the need to evaluate the autonomous and competent individuals regarding 4Cs (collaboration, creativity, critical thinking, and communication), and powerful self-constructs such as self-confident, self-regulated, self-efficient individuals becomes more acute (Erdogan, 2019; Hibbert \& Foncha, 2019).

Of all the educational theories, the present study argues that the implication of constructivist theory aligns most with the needs mentioned above throughout the previous centuries. However, the underlying demand remains to update and improvise the approach to function it in the most efficient way to deal with the $21^{\text {st }}$-century demands. These updating and adaptation practices of an approach are envisaged in the literature as the 'Practicing theory' process (Kumaravadivelu, 2003). Educators are expected to practice the constructivist approach with their promotional activities. In this frame, not only English language and teaching students, through constructivist theory addresses a wide range of audience ranging from Medical students, engineering students, to the Conservatory students as it targets to bring up self-efficient, self-regulated, and competent individuals.

The study also advocates that both $21^{\text {st }}$-century globalised world and constructivist theory share the same goals. A procedural link can be envisaged between these two concepts. However, in the current literature, the gap in research exists to review the needs of $21^{\text {st }}$-century language education under constructivist theory. Hence, the present study seeks to address this gap in the literature through reviewing the prominent literature. Additionally, the study follows a theoretically derived mode and model design that follows a constructivist approach in ELT and addresses the needs of the $21^{\text {st }}$-century. In doing so, the present study follows two research questions:

a. How does the constructivist theory of learning address the need of 21st century ELT requirements from students?

b. How do the existing studies perceive the design of a mode and model that follows the constructivist theory to address the $21^{\text {st }}$-century ELT requirements?

\section{Methodology}

The study follows a narrative literature review, which aims to review and critique relevant literature and offer a new conceptualisation derived from the previous literature (Snyder, 2019). In reviewing the literature, the study initially amplifies the $21^{\text {st }}$-century skills and constructivist learning theory intending to build a procedural link between the $21^{\text {st }}$-century skills with constructivist learning theory based on sharing similar outcomes. As the outcome of the narrative literature review, this link is followed up with the generation of the design of constructivist teaching in ELT classrooms in the $21^{\text {st }}$-century and defining the role of teachers and students, as established by the literature.

\section{21st-Century Skills}

To address the concerns of quality education, in 2002, academicians, politicians, educators, education experts, and researchers attempted to establish a non-governmental organization called Partnership21 (hereafter P21) (Brinkerhoff, 2002). This non-profit organisation describes its mission to identify and address students of all ages, starting from the pre-primary to the life-long learners. This organisation further attempted a round table meeting with educators from all over the world to smooth the integration of the learners to the $21^{\text {st }}$-century. The outcome from these attempts was the marginalisation of the various perspectives from the participants, which constituted a commonly accepted frame in 2007 (P21, 2007a), which incorporates interdisciplinary themes (Business, Economic, Financial, Global Awareness, Civil Literacy, Entrepreneurial Literacy, Health Literacy, and Environmental Literacy), and core subjects (English, Reading, World Languages, Arts, Mathematics, Language Arts, Economics, Geography, Science, History, and Government and Civics) (see Figure 1) 


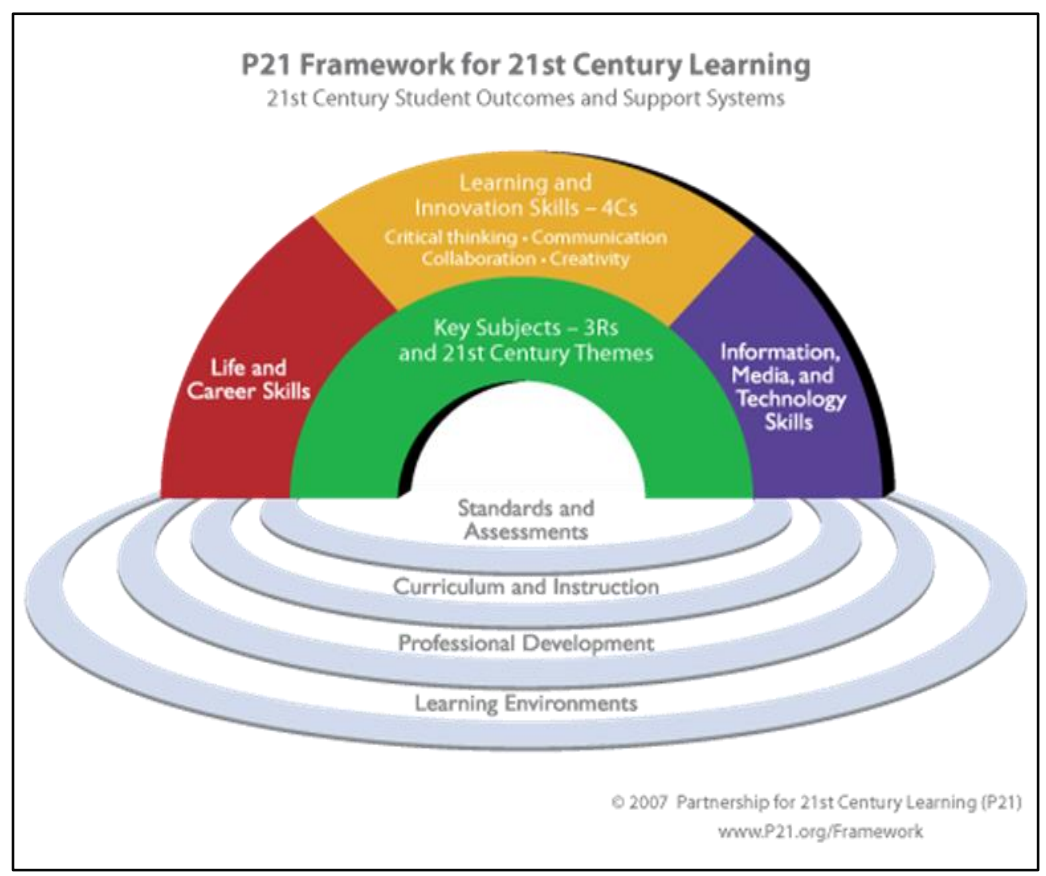

Figure 1. P21 Framework for 21st-Century Learning (adapted from P21, 2007a)

In the framework as depicted above, the main focuses of the themes and subjects are counted as learning and innovation skills, life and career skills, and information, media, and technology skills. The frame emphasises that the focal point for language education is learning and innovation skills. The literature further advocates that language educators and teachers widely appreciate the structure of learning and innovation skills introduced by P21. It clarifies the mastery of information and competencies required for the $21^{\text {st }}$-century (Lam, 2011). Graduates from higher education institutions are expected to be enabled with self-constructs to meet the career aspects demanded in the $21^{\text {st }}$-century (Haro-Soler \& Kiraly, 2019). At the same time, it is beneficial to underline that the change can still be made to prepare the learners for the $21^{\mathrm{st}}$-century and reconstruct the ill-equipped education.

The fundamental skills necessary for meeting the need of $21^{\text {st }}$-century, derived from the literature (Anagün, 2018; Chalkiadaki, 2018; Chu et al., 2016; Urbani et al., 2017) is amplified in the following table:

Table 1. Fundamental Skills for $21^{\text {st }}$-Century

\begin{tabular}{lcl}
\hline Key Domain & Essential skills for $21^{\text {st }}$-century learning and occupations \\
\hline Core subjects and skills & $>$ Reading \\
& $>$ Writing \\
\hline Learning and innovation skills & $>$ Critical thinking \\
& $>$ Problem-solving \\
& $>$ Creativity and innovation \\
\hline Career and life skills & $>$ Collaboration and teamwork \\
& $>$ Leadership and responsibility \\
& $>$ Initiative and self-direction \\
& $>$ Social and cross-cultural interaction \\
& $>$ Career and learning self-reliance \\
& $>$ Productivity and accountability \\
& $>$ Computing literacy \\
& $>$ Information literacy \\
& $>$ ICT literacy \\
& $>$ Media literacy \\
\hline
\end{tabular}


From the table above, it is evident that the interest areas of P21 are a context for learning, immediate assessment techniques, the language of instruction, and professional development. These items can be considered crucial considering the forth-coming centuries will also require the same needs of the $21^{\text {st }}$-century if the aim is to prepare auspicious generations (P21, 2009). However, learning and innovation skills emphasise real-life language teaching from a language education point of view (Bedir, 2019). This can be further established through placing communication, creativity, critical thinking and collaboration in classroom activities. When the 4Cs skills are perceived as the most effective skills for language education, the main objective of language education can be envisaged as 'Language for life' (Rankin \& Stegu, 2018). On the contrary, language education in the classrooms may also result in practising the theories of other cultures without analysing the suitability of the approach into the immediate classroom atmosphere or the main objective of the target language. From this point of view, the study advocates building a procedural link between the Constructivist theory and $21^{\text {st }}$-century requirements.

\subsection{Constructivist Theory}

Over the past centuries, the impact of educational theories on the learners' or even all individuals' learning habits has been researched and is still being explored by psychologists, philosophers, neuroscientists, linguists, and educational experts (Rankin \& Stegu, 2018). Monroe (1921) advocates that this search for theory has started from Greek philosophers with Socrates (469 - 399 BC), Plato (427 - 1347 BC), and Aristotle (384 - 322 BC). The movement continues even in the $20^{\text {th }}$-century (respectively) with Piaget $(1926,1955,1959,1970,1981)$, Bruner $(1960,1966)$, and Vygotsky (1978, 1980), and moves on with more modern researchers' popular studies: Bloom (1956) and Gardner (Bornstein \& Gardner, 1986; Gardner, 2000, 2006). These researchers have been searching for the meaning of the learning paradigm and its concise frame for the evolution of learning paradigms per the centuries' requirements.

The premise of constructivist theory is articulated by Jean Piaget (1955), who asserted that knowledge is internalised via certain mechanisms by humans. It is crucial to be aware that constructivism is not a pure pedagogy. Furthermore, a guidance theory describes how learners construct their knowledge from the instructed learning (Xu \& Shi, 2018). Constructivism circles around the reflections and their link with individuals' previous experiences (Baviskar et al., 2009). According to Tobias and Duffy (2009), constructivism design is a perfect match with 'Learning by doing' or 'Hands on' classroom activities from the perspective of active learners. The authors further advocate that at this point, $21^{\text {st }}$-century constructivism contradicts Piagetian Constructivism due to Piaget's distrust in learning by doing actions (empirical methods) and reliance on robotic activities (clinical practices). This shows the shift in the paradigm from behaviourism to cognitivism and from there eventually to constructivism.

According to Clark (2018), Gordon (2008), and Tobias and Duffy (2009), constructivism potentially seeks to promote a strong theory for describing how individuals internalise the meaning of the world with raw facts and formulate the new and individually different knowledge for themselves. Xu and Shili (2018) add in this regard that expertise is not outside and does not transfer by itself. Rather it can be discovered and gain new meaning through conversation, discussion, collaboration and construction. Butzler (2014) cites that constructivist theory highly supports learners' self-constructs through encouraging the discovery-learning process.

Among all the theories, the constructivist theory is one of the widely utilised theories in language education (Xu \& Shili, 2018). The theory advocates that every individual constructs their meaning. However, one of the major challenges of implementing this theory is the uncertainty of reaching an acceptable purpose regarding language education in the ELT classes (Riedener, 2019). Thus, teachers must observe and pay attention to students' learning process and keep it under the frame of collaboration and interaction (Zielinski, 2017). This offers a solution to maintain the information exchange among students under cooperation, communication, conversation frame until they achieve the meaning. The theory advocates that the teachers' responsibility is to provide students with controversial circumstances, creative, collaborative situations and monitor at the same time manipulate the process for the target outcome (Martin, 2019).

While before constructivism, two major theories were considered as the most prominent in understanding human learning-behavioural and cognitive theories: constructivism is enumerated here as the third main learning theory; since it incorporates the most probable instructional teaching design in it (Duffy \& Jonassen, 2013; Jonassen, 1991; Winn, 2013). On the one hand, these three theories overlap in many ways (Bergen \& Parsell, 2019; Guild \& Burke, 1997). On the other hand, these are quite distinct theories regarding explaining the learning process, and it can be justified as a rationale to treat them as discrete theories. As the arrow switches along the Published by Sciedu Press 
behaviourist-cognitivist-constructivist continuum, it is visible that interest areas switch from passive learning to active learning (Johnson \& Johnson, 2019).

Unlike behaviourism and cognitivism theories, constructivism theory has been recognised with different terminologies concerning the interpretations, practitioners, and classroom activities. Vadeboncoeur (1997) identifies three basic strands according to the interpretations of constructivism -Piagetian, sociocultural, and emancipatory constructivism. Consequently, these strands diversify respectively by (1) the subject of study, (2) views about how cognitive forms develop, and (3) "the liberatory power of the pedagogical approaches derived" (p. 22). However, among the aforementioned three constructivist interpretations, two of them- psychological constructivism (by Piaget) and social constructivism (attributed to Vygotsky) - is broadly recognized by educators. The major features which shape these interpretations are: (1) aiming to educate individuals as opposed to aiming to educate for the community (transmission of society), (2) the impact level of society on individual development (Richardson, 1997; Vadeboncoeur, 1997).

Apart from its sub-titles, names, and interpretations, constructivism incorporates a broad epistemology (a theory of obtaining the meaning of a concept from different perspectives) that presents ways humans can make meaning from nature or environment without direct instruction (Barger et al., 2018). Learners develop their understanding through constructing the link between the previous images, ideas, and beliefs from their experience and outside context without any repetition or imitation of any instruction from outside directly (Barger et al., 2018). In constructivist settings, learning activities are characterised via communication and collaboration, active engagement, inquiring about the presented information. Constructivist theory sustains educational practices under the circumstances of smooth transmission, which is enriched through a learning process instead of a didactic or one-way communication (Richardson, 1997). The basic futuristic element of constructivism is its reliance on dialogic knowledge transmission, which enables it to produce deeper understanding and better internalisation (Ivone et al., 2020).

\section{Discussion}

\subsection{The Implication of the Constructivist Theory of Learning in Achieving $21^{\text {st }}$-Century Requirements}

The following three strands, identified by Vadeboncoeur (1997), are amplified with response to $21^{\text {st }}$ century ELT.

\subsubsection{Piagetian (Psychological) Constructivism}

According to Piaget, constructing meaning is an individual psychological continuum, leading to a higher level of understanding by incorporating cognitive mechanisms (Piaget, 1959). The objective is to promote students' engagement with the complex real-life features and enter into re-construction process via combining former and further knowledge within the frame of the analytical cognitive maps. Psychological constructivism perceives the meaning construction process as an individual process and perceives the teachers as the facilitators of this re-construction process in two ways (Bergen \& Parsell, 2019). The first way is to design situations that intrigue motivation among the students, enabling them to be exposed to dissonance and create proper tasks. The second way the teachers can play the role of a facilitator is to tailor the students' proficient sides and encourage and establish their autonomy and self-constructs through tasks or projects. Hands-on activities, inquiry forms, and instructional activities are considered a means to capture students' attention and change their beliefs into hypotheses in a non-threatening classroom atmosphere. However, Richardson (1997) points out the concern that the immediate learning environment, in general, is the schools, which usually requires some forms of assessment and control mechanisms. Thus, unconditionally free meaning discovery may become a problematic issue from time to time. Under the controlled methods umbrella, ELT has been previously conducted through the utilisation of repetitive or imitative activities without the active participation of the students, which feeds to holding and examining the learners' learning outcomes.

However, language education in the $21^{\text {st }}$-century ELT classes enables the students to apply the knowledge in their real-life (Phongsirikul, 2017). In line with that, students are encouraged to think beyond the given scenario instead of previously conducted exam-oriented, syllabus-directed, and teacher-centred classes. In the ELT classes being analysed through the timeline of past decades to the present, constructivism reveals a flow from andragogy to heutagogy (self-determined learning). Within these two concepts, heutagogy claims individuals can regulate their learning process by taking ownership of the knowledge (Jones et al., 2019). On the other hand, andragogy is pursuing pedagogy to general adult education, which indicates it has certain borders (Jones et al., 2019). Although ELT was under hegemony of controlled activities in the past centuries, the present teaching-learning activities of English seeks to address the $21^{\text {st }}$-century. This advocates for the restricted educative activities to be either eliminated 
or minimised. In this regard, $21^{\text {st }}$-century ELT education is more vulnerable to societal constructivism than Piagetian constructivism. Piagetian constructivism promotes individual meaning construction in contrast to the collaboration and communication needs of the $21^{\text {st }}$-century ELT.

\subsubsection{Social Constructivism}

From the arguments as mentioned earlier, the concern can be raised that if (a) constructivist learning aims to meaning construction and (b) Piagetian constructivism is hindering the link among students, teachers, and society or the link between known and unknown constructs in the environment, and (c) the need of the $21^{\text {st }}$-century is to construct meaning through communication and collaboration; what can be the alternatives or a substitution for the Piagetian constructivism? Among the collaborative approaches for the learning process, the literature advocates that social constructivism is a better alternative to Piagetian constructivism (Bozkurt, 2017). Social constructivism differs from Piagetian constructivism specifically in terms of target audience: social constructivism aims at the whole society to reach the objective meaning rather than individuals. At this point, society is the instrument to achieve the target meaning. It has two approaches: situated cognition approach and sociocultural approach, as amplified below.

The situated cognition form of social constructivism advises that the meaning-making process is carried out through the collaboration of individuals with the environment. At the end of the process, both the knowledge base of the individual and the environment are reconstructed. In the school context, this activity is realised through student groups or student-teacher interactions. However, it is emphasised that the teachers need to take precautions to keep the atmosphere non-threatening. In this action, learning can occur in separation to interaction and the teaching is not directed to find 'Correct' answers (Richardson, 1997)

Sociocultural approach form of the social constructivism is derived from L.S. Vygotsky (Davydov \& Kerr, 1995; Moll, 1992; Wertsch, 2004; Al-khresheh, 2020), and it focuses on social interactions among the elements of society. In these social interactions, cultural forms gain meaning by the flow of the interaction. Society members then internalise those cultural meanings. In symbols and signs, formal information enters into situations, then affects or develops meanings. In doing so, raw materials change into meaningful pieces through cultural interpretations of signs or symbols. Vygotsky claims that all unknown life pieces gain importance in the Zone of Proximal Development through the facilitators' help. In this way, school subjects that are not of interest to the students or difficult to comprehend can gain new meanings via reconstruction in the ZPD.

\subsection{Deriving the Teaching Mode and Teaching Design through Constructivist Approach for $21^{\text {st }}$-Century ELT}

Students are the centre of constructivist learning theory. Within the years of adopting and interiorising the theory, teachers have needed to formulate new teaching ways suitable to constructivism mode and eligible for the $21^{\text {st }}$ century.

\subsubsection{The Mode of Constructivist Teaching in ELT Classrooms in the $21^{\text {st }}$-Century}

Compared to traditional one-way, teacher-centred teaching methods, teachers and students' roles have shifted drastically. According to Xu and Shi (2018), the constructivist theory emphasisses the major emphasis on students' ideas and considers them responsible for the cognition and active transmission of the knowledge construction. According to this theory, teachers only facilitate the learning as a mentor while students are the protagonist of the learning process. Among the four elements of constructivist setting -situation, conversation, collaboration, and meaning construction, problems are envisaged to be more conducive for students' deeper understanding and building their knowledge through $\mathrm{h}$ reconstructing upon their previous knowledge. Second, collaboration becomes an active process throughout the learning and is considered vital for compilation and examination of the knowledge and materials, and even for evaluation of the final meaning. The conversation is counted as the building block of collaborative actions. In this learning approach, group members are expected to always be in contact and discuss to reach out one final common meaning. Otherwise, individual learning activities may result in misunderstanding or misinterpretation of the knowledge and materials. Meaning construction is the outcome of this learning process. In the process, teaching is designed to facilitate the students for meaning construction, build links among the components of the concerned study, and achieve one common acceptable understanding of the link between inner thoughts and outer thoughts. These four elements are fundamental and vitally advised for preventing wrong interpretations.

In the mode of the $21^{\text {st }}$-century ELT classroom, the learning process also can be considered as free from setting such as virtual classrooms, flipped classrooms or inverted classrooms. The mode of those kinds of classrooms refers to the 
re-adjustment of time from the students' angel. The significance here is self-regulated and reached knowledge by students. The underlying idea in the $21^{\text {st }}$-century constructivist teaching mode is that learning is the student-centred environment where knowledge and meaning are socially constructed (Xu \& Shi, 2018).

To sum up and exemplify the teaching mode in ELT classrooms in the $21^{\text {st }}$-century relying on the constructivism and constructivist learning surrounding, roles must be conceptualised beforehand as in the follows: teachers are the mediator, organiser, and even helper while students are in the centre. The situation, collaboration, and communication are employed as the learning environment affecting factors to stimulate the students' enthusiasm and leading spirit. Thus, the mode can eventually aim to construct the present knowledge powerfully (He, 1997).

\subsubsection{The Design of Constructivist Teaching in ELT Classrooms in the $21^{\text {st }}$-Century}

Within the frame of awakening era through incorporating fast-paced technology in the field of education, educationalists seek to try to explore new ways to adopt constructivist theory in the $21^{\text {st }}$-century ELT classrooms to enrich the teachers with technological skill and enable them to utilise the skills in the teaching process. Schools are expected to place students as decision makers and knowledge builders, leading them to be individually successful, actively engaged, and academically productive. However, it is unrealistic and unnatural to presume the entire shifts in the current teaching process will occur at once. Inevitably this paradigm shift is time-consuming.

On the bright side, until now, there have been some noteworthy developments in achieving these goals. In the following, the design of constructivist teaching for the $21^{\text {st }}$-century is amplified, as derived from the literature.

As a first step, three aspects are placed as the most primary concerns- (a) externalising knowledge, (b) placing the students as centre and facilitate their autonomous learners, and (c) comprehend self-feedback. Second, the situation's role is considered the most significant at the meaning construction level. Through assimilation and adaptation, deeper understanding and novel meaning can be achieved successfully. As the third step, emphasis is given to collaborative (teamwork) learning. Interpretations arise from the interaction between the contexts and contend reciprocally. As the last step, the focus is on the learning process rather than the teaching process, which again implies the placing students at the center of this constructivist learning process. Holland (1997) explains that the environment fosters the improvements of attitudes; motivate both practices and practitioners to engage in the changing values. Given the students are surrounded by the proper conditions, they yield in the desired constructivist habits. In line with Holland (1997), designing the constructivist teaching environment is the common concern of both Richardson (2003) and Kemp (2011) as well. They claim that constructivist teaching design for ELT classroom is possible and appropriate with project-based learning approach (PBL) since both constructivism and PBL signals the student-centred approach. PBL is promoted in ELT classrooms to ensure positive interdependence, productive interactions, an active learning, personal accountability, and teamwork procedures. Apart from that, PBL makes both intrinsic and extrinsic commitment of the learning process possible for students.

To frame a clear analogy for design of constructivist teaching in an ELT classroom in the $21^{\text {st }}$-century, a sample classroom design is suggested to be as in following apart from adapting PBL approach;

\section{$>$ Place the social environment at the first row}

$>$ Be conscious of various points of view and welcome them

$>$ Keep in mind that teachers are the piece of the equation and not all of the equation

$>$ Value student understanding more than transmitting information

In considering the constructivist design and mode in the $21^{\text {st }}$-century ELT context, students should be enabled to discover and interpret freely through internet sources such as videos, audios, or text materials, and multimedia devices to accomplish their ultimate aims. While teaching was perceived as controlling and dominating in the traditional methods, in the $21^{\text {st }}$-century andragogy, ELT classes emphasised on autonomous learners with self-regulated, self-efficient, self-confident characteristics. Information on English grammar or basic language skills is no longer taught. They are expected to be discovered through guidance (Al-khresheh \& Orak, 2021). As an outcome of the implication of constructivist theory, long-term learning aims to be activated compared to behaviourism and cognitivism, considering learning through doing and discovering is placed in the long-term memory. That is why constructivist theory is highly popular in language education in the $21^{\text {st }}$-century heutagogy.

\subsubsection{Teachers' Role in the Constructivist Teaching in the $21^{\text {st }}$-Century Heutagogy}

Considering the main objective of the constructivist theory to promote active learning, teachers' role in this learning process is regarded as passive observers or mentors, who facilitate active learners to bridge the gap between Published by Sciedu Press 
knowledge and activity. Teachers in this process can be envisaged as scaffolders or facilitators rather than a tool to reproduce knowledge by pre-planned instructions. In this model, teachers are expected to encourage learners to always search for greater understanding by inquiring, overcoming the challenges with collaboration and communication, and reaching for a solution in a team. Teachers should de-emphasise the 'Correct' answers to the questions without reasoning or proving it with background information. This is another common point between $21^{\text {st }}$-century teacher model and the constructivist theory teacher model. In both teaching concepts, teachers and text-books are no longer the only information sources. They are expected to be treated as faithful supporter in the meaning construction process. Teachers harness the students by decreasing the external pressure of examination and devoting themselves to create encouraging self-pursuit of knowledge. In completing the meaning construction process, teachers' role should be not the only initiator of the motivation but also the sustainer of it till the learning outcome is achieved. In parallel to the advised teacher model of the $21^{\text {st }}$-century ELT classrooms, teachers are expected to promote the $4 \mathrm{Cs}$ - collaboration, communication, critical thinking, and creativity in the process of long-term learning.

\subsubsection{Students' role in the Constructivist Learning Process in the $21^{\text {st }}$-Century Heutagogy}

Under the scaffolding of teachers, constructivist theory advocates for student-centred learning. In line with this, the concerned theory comprises four elements: cooperation, conversation, situation, and meaning construction. These four elements are hypothesised to encourage, and activate students' passion for learning under the guidance of their teachers. That is how students complete meaning construction via the pioneering of initiators or enthusiasm presented in the immediate environment. Xu and Shi (2018) exemplify students' role in the constructivist learning process as the constructors facing complex real-life situations and are required to discover the meaning under the guidance of their teachers. Students are prepared as enabled to undertake cognitive strategies to form the meaning. They are expected to manipulate the whole learning process in contrast to traditional methods. They put the theory into practice, analyse the hypothesis or problems, and reach the most practical and long-term meaning. The common goal of both the constructivist theory and $21^{\text {st }}$-century ELT andragogy is to prepare efficient generations. So, it is not the only responsibility of the teachers or students; administers, stakeholders, evaluators of curriculums should all make changes in their ideology and face up with the learning and teaching facts of the constructivist theory and $21^{\text {st }}$-century globalised world.

\section{Conclusion}

The present study aims to show the common goals of both constructivist theory and $21^{\text {st }}$-century skills regarding ELT and how they are interlinked and can be practised simultaneously in the immediate educational institutions. Each century brings its own needs to every field of life, ranging from everyday to academic or career aspects. The area of education, especially language education, is on the priority of consideration regarding the reflections of the advancements. Technological advancements have turned the world into a global village in the $21^{\text {st }}$-century, and the English language has become the instrument of the communication of the so-called global village. Thus, it is of utmost importance to adopt an improvised trend of constructivism related to the acceleration of teaching and learning English in the long-term in the $21^{\text {st }}$-century.

The study offers a theoretically derived mode and model of ELT following a constructivist approach in achieving $21^{\text {st }}$-century learning requirements. Language education should be for life, and learners need to feel and internalise the language through experiences and discoveries to acquire it. In line with it, the $21^{\text {st }}$-century necessitates and expects more interactive and autonomous learners from educational institutions. Constructivist theory meets the requirements of the $21^{\text {st }}$-century global world since it has all the makings of the addressed pre-requisites.

Given that it is a review study, it is suggestable to conduct a research study with methodological triangulation and a high number of participations in cross-sectional studies to test the allegations in the concerned study in various contexts.

\section{Conflict of interests}

The authors have no conflict of interest.

\section{References}

Al-khresheh, M., \& Orak, D. S. (2021). The place of grammar instruction in the 21st century: Exploring global perspectives of English teachers towards the role of teaching Grammar in EFL/ESL Classrooms. World Journal of English Language, 11(1), 9-23. https://doi.org/10.5430/wjel.v11n1p9 
Al-khresheh, M. (2020). The impact of cultural background on listening comprehension of Saudi EFL students. Arab World English Journal, 11(3), 349-371. https://doi.org/10.24093/awej/vol11no3.22

Anagün, Ş. S. (2018). Teachers' perceptions about the relationship between 21 st century skills and managing constructivist learning environments. International Journal of Instruction, 11(4), 825-840. https://doi.org/10.12973/iji.2018.11452a

Barger, M. M., Perez, T., Canelas, D. A., \& Linnenbrink-Garcia, L. (2018). Constructivism and personal epistemology development in undergraduate chemistry students. Learning and Individual Differences, 63, 89-101. https://doi.org/10.1016/j.lindif.2018.03.006

Baviskar, S. N., Todd Hartle, R., \& Whitney, T. (2009). Essential criteria to characterize constructivist teaching: Derived from a review of the literature and applied to five constructivist-teaching method articles. International Journal of Science Education, 31(4), 541-550. https://doi.org/10.1080/09500690701731121

Bedir, H. (2019). Pre-service ELT teachers' beliefs and perceptions on 21st century learning and innovation skills (4Cs). Journal of Language and Linguistic Studies, 15(1), 231-246. https://doi.org/10.17263/jlls.547718

Bergen, P., \& Parsell, M. (2019). Comparing radical, social and psychological constructivism in Australian higher education: a psycho-philosophical perspective. In Australian Educational Researcher, 46(1). SAGE Publications. https://doi.org/10.1007/s13384-018-0285-8

Bloom, B. S. (1956). Taxonomy of educational objectives. Cognitive domain. New York: McKay, 20, 24.

Bornstein, M. H., \& Gardner, H. (1986). Frames of Mind: The theory of multiple intelligences. Journal of Aesthetic Education, 20(2). https://doi.org/10.2307/3332707

Bozkurt, G. (2017). Social constructivism: Does it succeed in reconciling individual cognition with social teaching and learning practices in mathematics? Journal of Education and Practice, 8(3), 210-218. Retrieved from https://eric.ed.gov/?id=EJ1131532

Brinkerhoff, J. M. (2002). Government-nonprofit partnership: A defining framework. Public Administration and Development, 22(1), 19-30. https://doi.org/10.1002/pad.203

Bruner, J. (1960). On learning mathematics. The Mathematics Teacher, 53(8), 610-619. https://doi.org/10.5951/MT.53.8.0610

Bruner, J. (1966). Toward a theory of instruction. Harvard University Press.

Butzler, K. B. (2014). The effects of motivation on achievement and satisfaction in a flipped classroom learning environment. Northcentral University.

Chalkiadaki, A. (2018). A systematic literature review of 21st century skills and competencies in primary education. International Journal of Instruction, 11(3), 1-16. https://doi.org/10.12973/iji.2018.1131a

Chu, S. K. W., Reynolds, R. B., Tavares, N. J., Notari, M., \& Lee, C. W. Y. (2016). 21st century skills development through inquiry-based learning: From theory to practice. 21st Century Skills Development Through Inquiry-Based Learning: From Theory to Practice. Springer. https://doi.org/10.1007/978-981-10-2481-8

Clark, K. R. (2018). Learning theories: constructivism. Radiologic Technology. Retrieved from http://www.radiologictechnology.org/content/90/2/180.extract

Davydov, V. V., \& Kerr, S. T. (1995). The influence of L. S. Vygotsky on education theory, research, and practice. Educational Researcher, 24(3), 12-21. https://doi.org/10.3102/0013189X024003012

Duffy, T. M., \& Jonassen, D. H. (2013). Constructivism and the technology of instruction: A conversation. constructivism and the technology of instruction: A Conversation. https://doi.org/10.4324/9780203461976

Estaji, M., \& Savarabadi, M. (2020). English as an international language: Reconstructing EFL teachers' cultural awareness and perception of teaching culture. The Journal of English as an International Language, 15(1), $82-99$.

Erdogan, V. (2019). Integrating 4C Skills of 21st Century into 4 Language Skills in EFL Classes. International Journal of Education and Research, 7(11), 113-124. www.ijern.com

Flores, N., \& Chaparro, S. (2018). What counts as language education policy? Developing a materialist Anti-racist approach to language activism. Language Policy, 17(3), 365-384. https://doi.org/10.1007/s10993-017-9433-7 
Gardner, H. (2000). Intelligence reframed: Multiple intelligences for the 21 st century. Hachette UK.

Gardner, H. (2006). Changing minds: The art and science of changing our own and other peoples minds. Harvard Business Review Press.

Gordon, M. (2008). Between constructivism and connectedness. Journal of Teacher Education, 59(4), 322-331. https://doi.org/10.1177/0022487108321379

Guild, \& Burke, P. (1997). Where Do the learning theories overlap? Educational Leadership, 55(1), 30-31. https://eric.ed.gov/?id=EJ550528

Haro-Soler, M. del M., \& Kiraly, D. (2019). Exploring self-efficacy beliefs in symbiotic collaboration with students: an action research project. Interpreter and Translator Trainer, 13(3), 255-270. https://doi.org/10.1080/1750399X.2019.1656405

Hibbert, L., \& Foncha, J. (2019). Improving Student's Performance in English as Language of Learning and Teaching in Teacher Pre-service Education. The Journal of English as an International Language, 14(2), 29-43.

Holland, J. L. (1997). Making vocational choices: A theory of vocational personalities and work environments (3rd ed.). Odessa FL: Psychological Assessment Resources.

Ivone, F. M., Jacobs, G., \& Santosa, M. H. (2020). Information and communication technology to help students create their own books the dialogic way. Beyond Words, 8(2), 78-91. https://doi.org/https://doi.org/10.33508/bw.v8i2.2545

Johnson, R., \& Johnson, D. (2019). Active learning - Beyond the future. In S. M. Brito (Ed.), Active Learning Beyond the Future. IntechOpen. https://doi.org/10.5772/intechopen.73460

Jonassen, D. H. (1991). Objectivism versus constructivism: Do we need a new philosophical paradigm? Educational Technology Research and Development, 39(3), 5-14. https://doi.org/10.1007/BF02296434

Jones, C., Penaluna, K., \& Penaluna, A. (2019). The promise of andragogy, heutagogy and academagogy to enterprise and entrepreneurship education pedagogy. Education and Training, 61(9), 1170-1186. https://doi.org/10.1108/ET-10-2018-0211

Kekang, H. (1997). Constructivism teaching mode, method and design. Journal of Beijing Normal University, 5(75), 78-81.

Kemp, S. (2011). Constructivism and problem-based learning. Learning Academy, 45-51.

Keser, H., \& Semerci, A. (2019). Technology trends, Education 4.0 and beyond. Contemporary Educational Researches Journal, 9(3), 39-49. https://doi.org/10.18844/cerj.v9i3.4269

Kumaravadivelu, B. (2003a). A postmethod perspective on English language teaching. World Englishes, 22(4), 539-550. https://doi.org/10.1111/j.1467-971X.2003.00317.x

Kumaravadivelu, B. (2003b). Beyond methods: macrostrategies for language teaching. Choice Reviews Online, 41(3). https://doi.org/10.5860/CHOICE.41-1693

Lam, W. L. K. (2011). Yong Zhao: Catching up or leading the way: American education in the age of globalization. Journal of Educational Change, 12(1), 99-107. https://doi.org/10.1007/s10833-010-9145-7

Mahdum, M. (2018). Language Education. Proceedings of the UR International Conference on Educational Sciences, $29-40$.

Martin, N. (2019). From containment to realpolitik and back again: A realist constructivist analysis of Turkey-EU relations and the migration Issue. Journal of Common Market Studies, 57(6), 1349-1365. https://doi.org/10.1111/jcms. 12947

Moeller, A. J., \& Abbott, M. G. (2018). Creating a new normal: Language education for all. Foreign Language Annals, 51(1), 12-23. https://doi.org/10.1111/flan.12310

Moll, L. C. (1992). Bilingual classroom studies and community analysis: Some recent trends. Educational Researcher, 21(2), 20-24. https://doi.org/10.3102/0013189X021002020

Monroe, P. (1921). A text-book in the history of education. Macmillan.

Phongsirikul, M. (2017). A learner of the 20 th century becoming a teacher of the 21 st Century: A perspective on the goals of ELT in Thailand. REFLections, 24, 81-94. Retrieved from 
https://so05.tci-thaijo.org/index.php/reflections/article/view/112295

Piaget, J. (1926). The language and thought of the child. New York: Harcourt, Brace.

Piaget, J. (1955). The construction of reality in the child. Psychoanalytic Review, 42(3), 313-314.

Piaget, J. (1959). The psychology of intelligence. Routledge and Kegan Paul.

Piaget, J. (1970). Science of education and the psychology of the child. Trans. D. Coltman. Orion.

Piaget, J. (1981). The psychology of intelligence. Routledge.

Raja, R., \& Nagasubramani, P. C. (2018). Impact of modern technology in education. Journal of Applied and Advanced Research, 3(1), 33-35. https://doi.org/10.21839/jaar.2018.v3iS1.165

Rankin, T., \& Stegu, M. (2018). Language for life: educational, professional and social contexts. Taylor \& Francis. https://doi.org/10.1080/09658416.2018.1433492

Richardson, V. (Ed.). (1997). Constructivist teacher education: Building new understandings. Psychology Press.

Richardson, V. (2003). Constructivist pedagogy. Teachers College Record, 105(9), 1623-1640. https://doi.org/10.1046/j.1467-9620.2003.00303.x

Riedener, S. (2019). Constructivism about intertheoretic comparisons. Utilitas, 31(3), 277-290. https://doi.org/10.1017/S0953820819000165

Snyder, H. (2019). Literature review as a research methodology: An overview and guidelines. Journal of Business Research, 104, 333-339. https://doi.org/10.1016/j.jbusres.2019.07.039

Tobias, S., \& Duffy, T. M. (2009). Constructivist instruction: Success or failure? Routledge. ttps://doi.org/10.4324/9780203878842

Urbani, J., Roshandel, S., Michaels, R., \& Truesdell, E. (2017). Developing and modeling 21st-century skills with preservice teachers. Teacher Education Quarterly, 44(4), 27-50.

Vadeboncoeur, J. A. (1997). Child development and the purpose of education: A historical context for constructivism in teacher education. In Virginia Richardson (Ed.), Constructivist teacher education: Building new understandings (15-18). Taylor \& Francis Group. https://doi.org/10.4324/9780203973684

Vygotsky, L. S. (1978). Socio-cultural theory. Mind in society, 6, 52-58.

Vygotsky, L. (1980). Mind in society: The development of higher psychological processes. Harvard university press. https://doi.org/10.2307/j.ctvjf9vz4

Wertsch, J. V. (2004). A sociocultural approach to socially shared cognition. Perspectives on socially shared cognition. (pp. 85-100). American Psychological Association. https://doi.org/10.1037/10096-004

Winn, W. D. (1991). The assumptions of constructivism and instructional design. Educational technology, 31(9), 38-40. https://doi.org/10.4324/9780203461976

Xu, Z., \& Shi, Y. (2018). Application of constructivist theory in flipped classroom - Take college English teaching as a case study. Theory and Practice in Language Studies, 8(7), 880. https://doi.org/10.17507/tpls.0807.21

Zielinski, D. E. (2017). The use of collaboration, authentic learning, linking material to personal knowledge, and technology in the constructivist classroom: Interviews with community college faculty members. Community College Journal of Research and Practice, 41(10), 668-686. https://doi.org/10.1080/10668926.2016.1220338

\section{Copyrights}

Copyright for this article is retained by the author(s), with first publication rights granted to the journal.

This is an open-access article distributed under the terms and conditions of the Creative Commons Attribution license (http://creativecommons.org/licenses/by/4.0/). 